銅鉱の少なくとも一部の生成温度は比較的高温を推定しなければならない。このことは

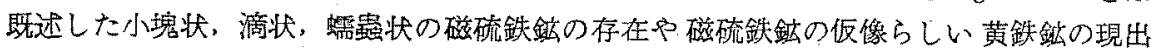
によつて更に赛付されるが，特殊な鉉床生成の条件例え壮水その他の存在等で上記の奏 釦温度が著しく低下する様なことも考えられ，もつと多く他の方面办ら資料を策めた上

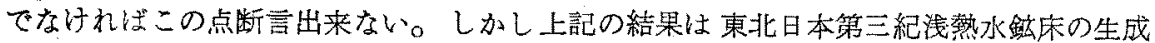
温度に関する参考資料として重要視さるべきで，今後かるる見地より上記浅熱水鉱床を 観察してみる必要がある。

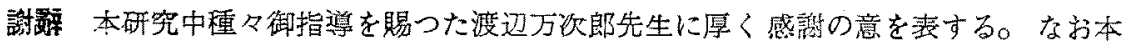
研究に要した費用の一部は文部少科学研究費による。こ〉に朋記して謝意を素する。

\title{
日高国ホロベツ川上流(ニオベツ川）の湿成岩体に見出さ扎た 斜長石柘榴石紫蘇辉石角閃石岩の流石*
}

The plagioclase garnet hypersthene hornblende rock as a block on the River Horobetsu (the River Niohetsu), in the central migmatite bodies, Hidaka province.

$$
\text { 浅 贲** (Hiroshi Asai) }
$$

\footnotetext{
Abstract: The writer describes the petrographical chracters of the plagioclase garnet hypersthene hornblende rock found as a block on the River Horobetsu, Hidaka prov. and gives some considerations on its genesis.
}

\section{I むえが}

1954年 7月，日高国示ロヘツ川上流（ニオペツ川）の塩基性岩数及びミグマタイトを 調查する機会に惠まれた。その時，日高，十勝両国の国境附近に於て，塗长石椎榴石紫

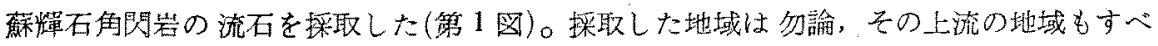

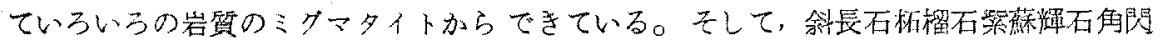

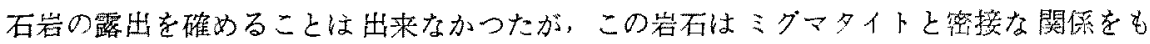
つて露われているものと考えられる。

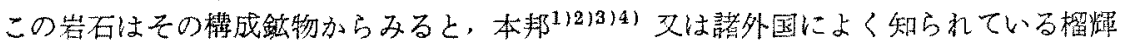

日本地翼学会札兟支部例会講演，1955年 5 月

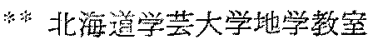

1) Suzuki, Z. ; Jour. Fac. Sci. Hokkaido Imp. Univ, Ser, IV. 1, 1930

2) 胸怨; 東大卒諭 (手部)，1933

3) 堀越義一; 地質，44，141 144，1937

4) 石川俊夫; 岩碳, 36, 42 46, 1952 
岩及は榴輝岩筫岩石とよく以ているが，鉱物成分及びその性状が異つていて，エスコラの

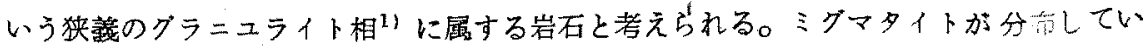
る地域に此の様な岩石肪あると考えられることは，ミグマタイトが幾度かの変㖶を経て も尚，角閃岩相を示しているのに比較して，その岩質が極めて特珙なものなのである。 そしてミグマタイトと此の様な特異な岩石とが共存すると考えられる事は閶接的にミグ マタイトの生成される困難な条件を逆に知ることが出来ると思われる。

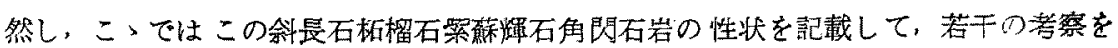
行うこととする。

尚本地域は既に鈴木守，佐藤博之によつて，最近，調查せられだ。

第 1 困 斜長石榀榴石管蕉輝

石角閃石岩を採取し た位置……... 印

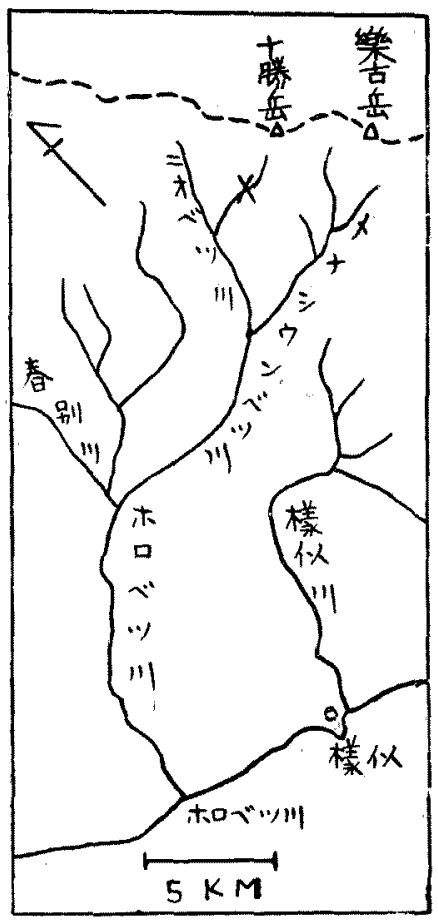

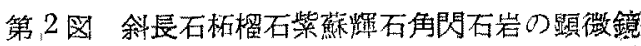
のスケツチ

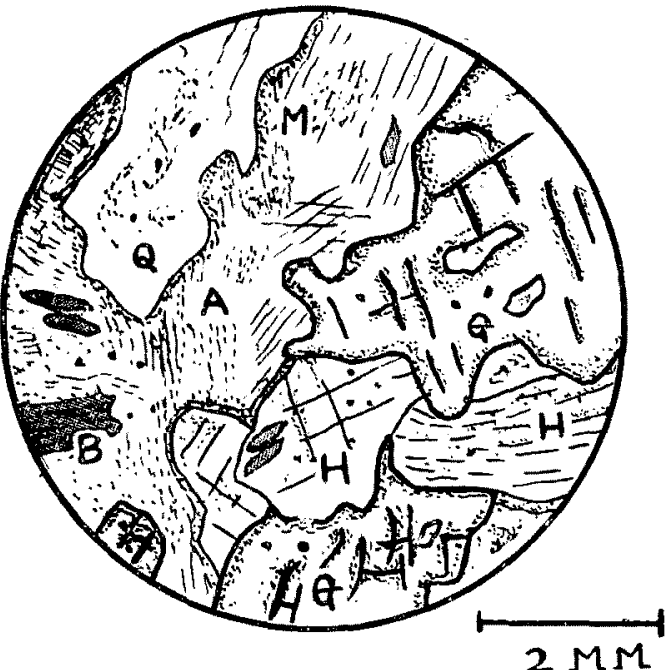

$Q \cdots \cdots \cdot$ 石英, 斜長石,

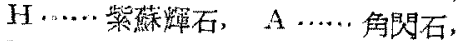

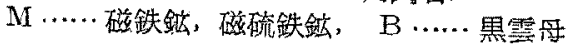

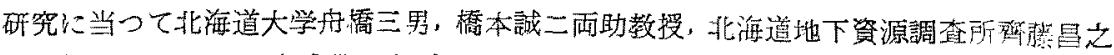

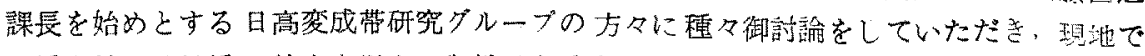

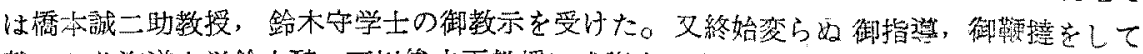

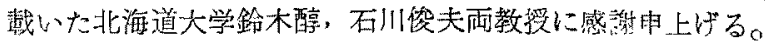

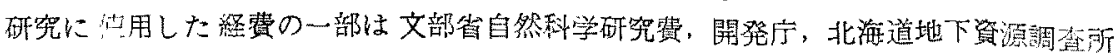

1) Eskola, P.; Geol. Fören. I Stockholm Förhd1., 1929

2) 鉻圭守, 优藤缚之; 北大修論, 1952 
の御援助に負う所が多く当局に感謝を棒げる次第である。

\section{II 外霍}

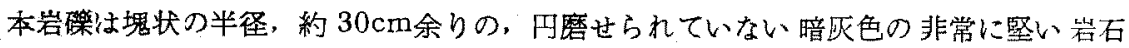
で：紅褐色の柘榴石が暗灰緑色の素地の中に散点している。

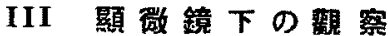

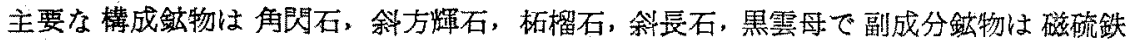

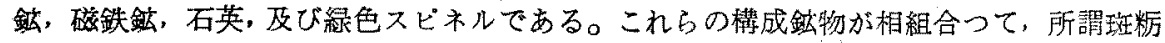
岩の構造を示すか及は部分的にオフィテツク䊔造を示している。（第 2 図）

上に述べた岩石を比較の茇に之と上く似た本邦に産出する榴輝岩，及は榴買角聞岩の 鉣物を 第 1 表に示した。尚, 本岩石のモードの一例を第2表に示しだ。

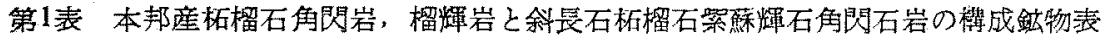
）内の鉱物名は比較的少量の成分

\begin{tabular}{|c|c|c|c|c|}
\hline \multicolumn{3}{|c|}{ 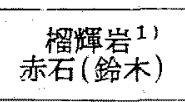 } & $\begin{array}{c}\text { 榴輝岩 }{ }^{22} \\
\text { 東赤石山(瓷越) }\end{array}$ & $\begin{array}{l}\text { 榴燀角閏岩3) } \\
\text { 吉野川(流石) } \\
\text { (石!川) }\end{array}$ \\
\hline 柘 & 榴 & 石 & 杬 榴 & \multirow{13}{*}{ 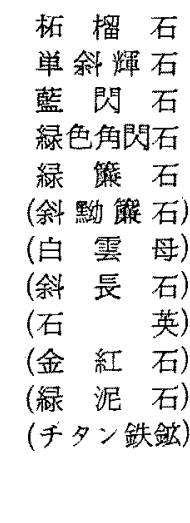 } \\
\hline 緑 & 輝 & 石 & 透 罩 石 & \\
\hline （藍 & 聞 & 石) & 頑火踽石 & \\
\hline 白 & 雲 & \& & 橄 欖 石 & \\
\hline (斜) & 衾 & 石) & (角 閃石) & \\
\hline 石 & & 英 & (緑 籍 石) & \\
\hline （金 & 紅 & 石) & (斜黝箖 石) & \\
\hline (緑 & 泥 & 石) & （曹 長 石) & \\
\hline \multirow[t]{5}{*}{ （橎 } & & 石) & 石) & \\
\hline & & & (緑 泥 石) & \\
\hline & & & $\begin{array}{l}\text { (干多之鉄鉱， } \\
\text { 磁鉄锌) }\end{array}$ & \\
\hline & & & (榀石) & \\
\hline & & & (燐 灰 & \\
\hline
\end{tabular}

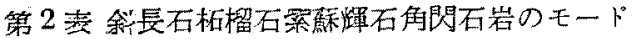

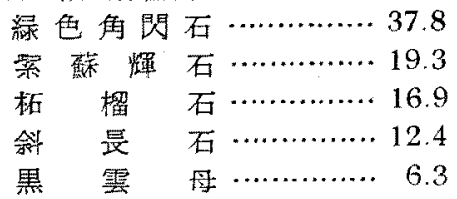

磁硫鉄鉣，磁鉄銥，緑色スビンネル…....4.2

石

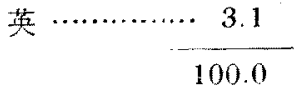

(炻榴石が比較的多小部分)

斜長石析榴石策篗輝在角門石 岩ホロベッ川(流石)(浅井)

柘. 榴 石

淡桃色, $\mathrm{N}_{580} \mu \mu=1.834$ $\mathrm{G}=3.862$

紫葆煇石

X…明るい黄色

$\mathrm{Y} \cdots$ くすんだ黄色

Z …緑青色

$2 \mathrm{~V}(-) \ldots 72^{\circ}, 77^{\circ}$

$\mathrm{n}_{2}=1.720$

緑色角閃石

X…明るい黄色

Y…や〉くすんだ黃色

Z…や〉こい緑黄色 及はうす心青色

$2 \mathrm{~V}(-) \ldots 72^{\circ}, 92^{\circ}$

$c \wedge Z=14^{\circ}, 15^{\circ}, 16^{\circ}$

$\mathrm{n}_{2}=1.687$

黑雪居

X…うする褐出

Y，Z…暗小褐色

$\mathrm{n}_{2}=1.657 \sim 1.548$

金曼石

$A n_{55}, A_{58}, A n_{80}, \mathrm{An}_{42}$, $\mathrm{An}_{43}$

(石英)

(磁硫鉄鏔，磁鉄鉏)

(縁色スビネル)

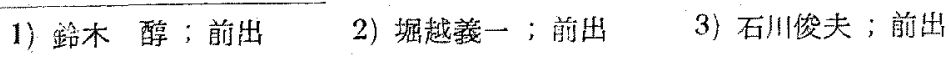




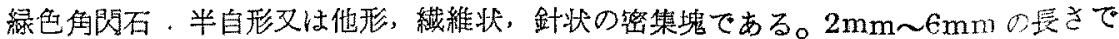
巾は $0.04 \mathrm{~mm}$ 位の舆針状のものがある。及、紫蘇輝石の周囲を取りまいていることがあ る。污染していて，内部に微細な一定の配列をもつか，或は不挸則な配列を持つた微粉

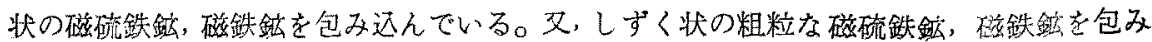
込む二とがある。一定の配列を示した微細な磁硫鉄鉱，磁鉄鉉は黒雲母再消失してその 䢃聞に沿つて，乙等を排出した如くなつている(第 3 図)。又，斜長石に接している部分 が青空出になつているこにがある。

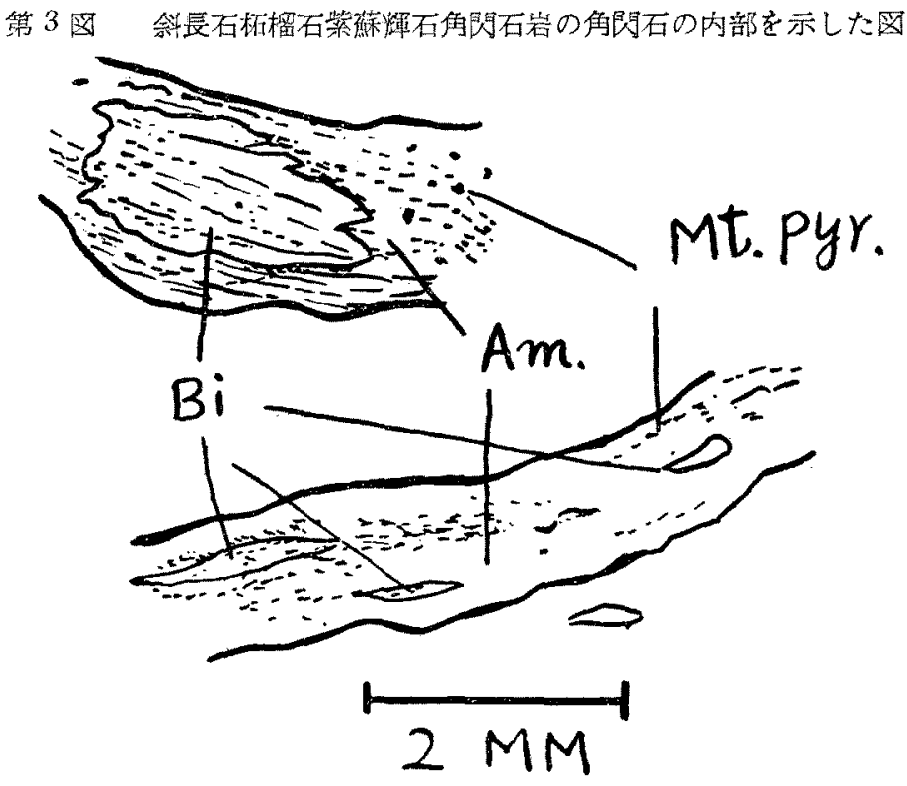

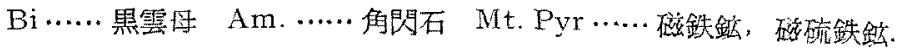

柔蘇輝石：自形页は半自形を示す。長径 $2.8 \mathrm{~mm}$, 短径 $2 \mathrm{~mm}$ に卖する。多色性か

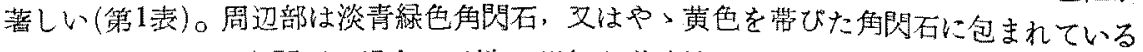

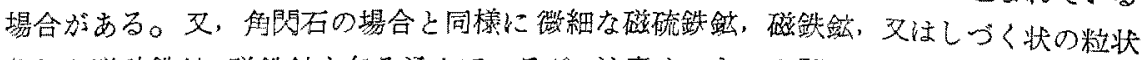

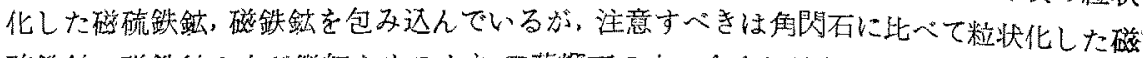

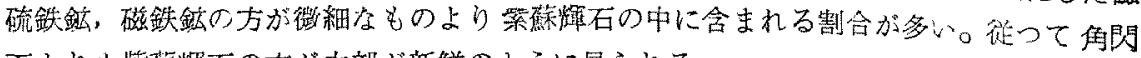

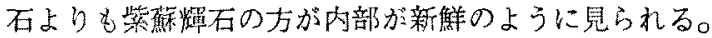

柏榴石：自形文は半自形の大晶で $2 \mathrm{~mm} \sim 6 \mathrm{~mm}$ 内外の直条を持つている。㓶目が多

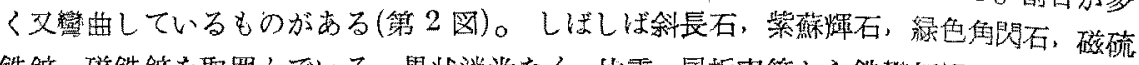

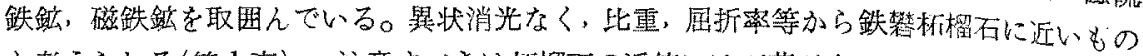

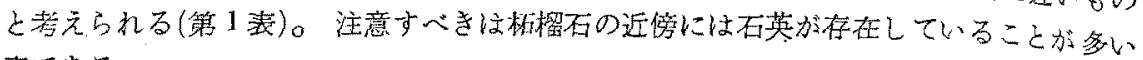
整である。

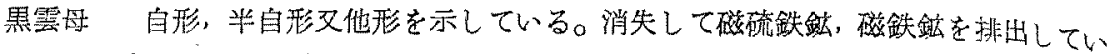
るもの，双自形を示して他の鉱物の聞をうずめているもの，消失しながら粒状化して終 
つたものがある。自形を示すもの以外は他の鉣物に包み込まれている。

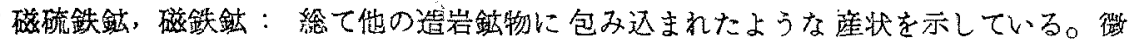
細な粉状のもの，や>粗粒で円形又はしつくく状を呈して粒状化したものがする。角周石 の項で述べたように之等は黒雲母の消失によつて生成せられたものである。

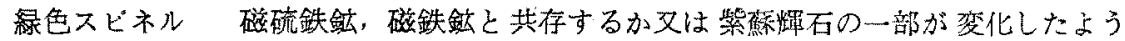
な性状を示している。不定形で微細なものが多い。

\section{IV 考察}

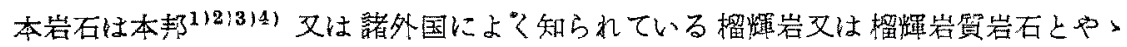
その性状を翼にしていることは第I表に示した如くである。特質的なことは箱套辉石， 斜長石，褁墨四多量に見られることがある。

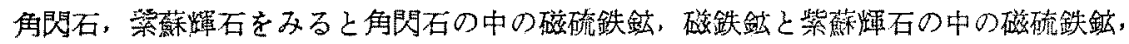
磁鉄銥己ではその性状が異なり紫蘇輝石に含まれるものの方が粗粒で粒状化しているも のが多、。したがつて角間石に比へて紫櫯煇石は新鮮で污れが少ない。角閔石の中の磁

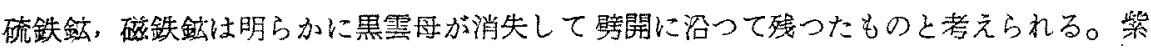

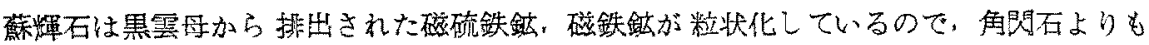
高度の变成条件に持ち来たされたものの様である。そして未だ消失しなかつた黒会航は

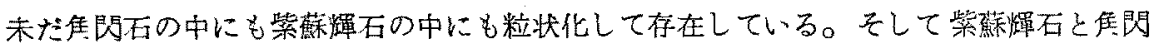
石との関係は主に侮閝石が紫蕉輝石の周りに生成せられている如く見られるが，又全く両

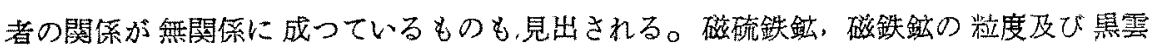

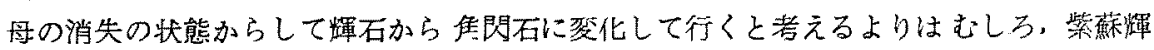

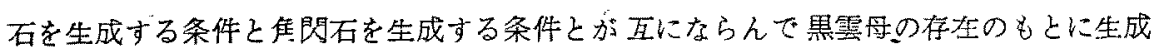
したものと考えられる。この事はくり加えし述へた如く黒雲度の消失した残りの排出物 である磁硫鉄鍼，磁鉄鉏の粒状化の程度によつて明らかである。即方紫蘇煇石の生成俚 刍聞石生成よりもより高度の条件に持亏来たされたものと思われる。即ち本岩は著しい 黒雲䍡の漊集と消散による交代岩であると考えることが出来る。

而してこの岩相はターナー、フェルホーダンがのいうグラニッライト岩相のうちで紫 蘇輝石一板㨨石の組合せにあたるすのと哮えられる。

本岩は日高变成带の中央部にあるミグマタイト岩体中に存在するものと考えられるが， この地带のミグマタイト化の一專の变成作用の中途でこのような㱆しい交代作用䘮部分 的に受けて形成せられたものであろう。

南部日高変成蒂に於ては比䡈的西側によつた部分に多くの塩基性岩死が菅状に配列し ている6゙が，著しい高温と偏圧条件に持ち来たされた交代性の岩石で，特に本岩と親縁の
1) Suzuki, Z. ; 前出
2) 岡 忍; 前出
3) 堀越義一; 前出
4) 百川倿夫; 前出
5) Turner, F. J., Verhoogen, J. : Igneous and metamorphic petrology. 1952
6) 拆橋三男, 橋本誠二；地团研專坏，6 
関䋆にあると考元られる輝石片麻岩類はやはり非常に高度の条件に持も来たされて，交 代作用の結果生成せられた岩石であることは既に述へだ本岩のような䇹石が苳成带の 中央部に於て保在する可能性が大きいことは南部日高変成带の中央部に於ても传成带の 西側の㙁基性岩䅠の生成の条件と同一の条件に持ち来たされた部分があったことを示し ている。

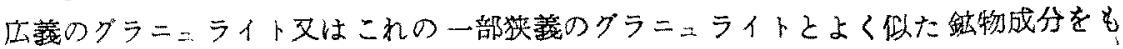

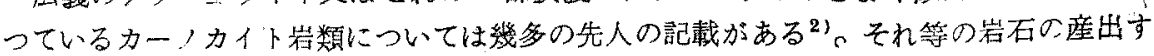
る主なる区域をあげると南極大陸の一部のアデリー3!，ールウェー4), 13!。オーストリー

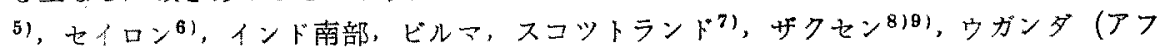

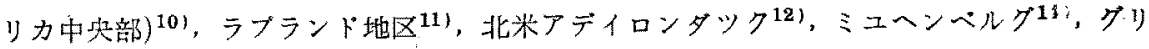
ーンランド 15!，16!，北朝鮮17)等である。

最近は，ターナー及びヘルホーゲン181 バート ${ }^{191}$ ，ランベルク゚等が詳細に論じてい る。

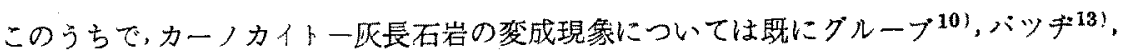

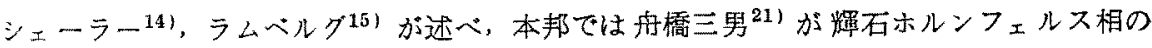

1) 淺并宏；日本地質学会総会講演，1955，4月

2) 山口責雄が述ベている如くグラニュライトという名称の中には狭義のグラニュライ

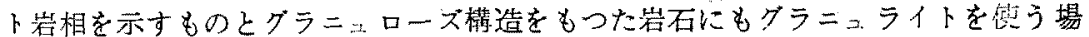
合がある。匝義のグラニニライトとはこの両者の岩石をさしている。山口貴雄：

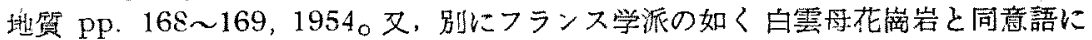

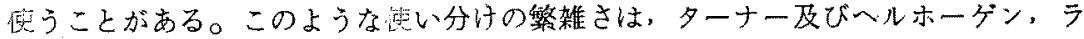
ンベルグ等が詩細に諭及している。

3) Stillwell, F. L. ; Sci. Repts. Ser. A, Vol. 3, Pt. I, 128 198, 1918

4) Goldschimdt, V. M. ; Norske. Vid Akad. Skr. 1, 1922

5) Waldmann, L. ; Mitt. Geol. Ges. Wien, 20, 1927

6) Adams, F. D. ; Canadian Jour. Research, 1, 444 498, 1929

7) Harker, A. F.; Metamorphism. 310 314, 1932

8) Scheumann, K. H. ; Ber. Sächs. Akad. Wiss. Math.-Phys. K1. 47, 1935

9) Scheumann, K. H. ; Min. Pet. Mitt., 47, 403 469, 1936

10) Groves, A. Wr. ; Quat. Jour. Geol. Soc, 91, 150, 1935

11) Shama, T. ; Comm. Géol. Finland, Bull. 113, 1 110, 1936

12) Buddington, A.F. ; Geol. Soc. Amer. Mem. 7, 1939

13) Bugge, J. A. W. ; Norg. Geol. Undersökelese, No. 160, 1943

14) Schüller, A. ; Heiderberg Beitr. (2) Miner. Petrog., 1, 269, 1948

15) Ramberg, H. ; Jour. Geol. 57, 17, 1949

16) Ramberg, H. ; Medd. Dansk. Geol. Foren., 12, 1951

17) 山口貴雄 ; 地筫 57, 419 437, 1951

18) Turner, F. J., Verhoogen J. ; Igneous and metamorphic petrology. 473 $\sim 477,1952$

19) Barth, T. F. W. ; Theoretical petrology. 343 347, 1952

20) Ramberg, H. ; The origin of metamorphic and metasomatic rocks. $156 \sim$ 164,1952

21) 舟祜三男 ; 北大理学部紀要, Ser. IV, 8, 1948 
形成されるときに本岩石の性状と同様の現象について観察した。

本岩石で見られるような生成機榡が南部日滈㚆成带の变成作用の如何なる時期に組み いれらみへきかという問題については別の機会に詳远する。

\title{
天龍川地域三波川変成带の塩基性おょび 超塩基性岩*
}

The basic and ultrabasic rocks of the Sanbagawa metamorphic region in the Tenryu river basin.

$$
\text { 中山勇 (Isamu Nakayama)** }
$$

\begin{abstract}
In the Sanbagawa metamorphic region of the Tenryu river basin, the basic and ultrabasic intrusion can be divided into the following three stages.

1st stage: The synkinematic intrusion of sills of "Topfstein" and epidote-amphibolite. The later was derived from a basic intrusive rock. Accompanying the intrusion of these rock, the crystalline schist were subjeoted to metasomatisms which were formed of the albitization and the chloritization.

2nd stage: The intrusicn of saussurite gabbro, periodtite, metadiabase and amphibolite. The latest was derived from basic and ultrabasic rocks. In the last of this stage, the banded rock, is ccmpcsed of the peridotite and the saussurite gabbro, intruded into the space (Mikabu Zone) between the crystalline schist and the non-metamorphic palaeczoic rock.

3rd stage: The intrusion of the serpentin was accompanied by the fault.
\end{abstract}

\section{Iまえかき}

天竜川地域の三波川変成带の層序と模造については，すでに報告しだのここの論文で はこの地域の塩基性㧍よび 超塩基性岩の逆入が, 三波川結晶片岩の変成作用と，とんな 関係にあるか，塩基性岩・超塩基性岩類か，互にどんな関係にあるかを述べるこの論文 をかくにあたつて，討論して下さつた吉沢甫，岩陭正夫の両氏，プレバラートを作つて 下さつた河山平三郎氏，現地で色々とお世話になった大橋国吉，内山武司の両氏，図版 をつくる上にあたつてお世話して下さつた加藤不二黑氏に，阙意を表する。

*1955年. 日本地頯学会年会諯演。

**宗都大学理学部地筫学銥物学教室。

1) 中山爱；地質，59，1953., I. Nakayama; Mem. Coll. Sci. Univ. Kyoto, Ser. B. 21, 1954 